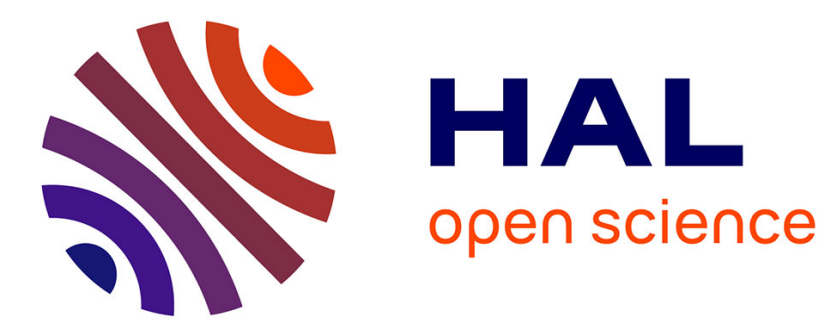

\title{
THE LINK BETWEEN NON TECHNOLOGICAL INNOVATIONS AND TECHNOLOGICAL INNOVATION
}

\author{
Thuc Uyen Nguyen-Thi, Caroline Danièle Mothe
}

\section{- To cite this version:}

Thuc Uyen Nguyen-Thi, Caroline Danièle Mothe. THE LINK BETWEEN NON TECHNOLOGI-

CAL INNOVATIONS AND TECHNOLOGICAL INNOVATION. European Journal of Innovation Management, 2010, 13 (3), pp.313-332. hal-00920069

\section{HAL Id: hal-00920069 \\ https://hal.science/hal-00920069}

Submitted on 27 Jan 2014

HAL is a multi-disciplinary open access archive for the deposit and dissemination of scientific research documents, whether they are published or not. The documents may come from teaching and research institutions in France or abroad, or from public or private research centers.
L'archive ouverte pluridisciplinaire $\mathbf{H A L}$, est destinée au dépôt et à la diffusion de documents scientifiques de niveau recherche, publiés ou non, émanant des établissements d'enseignement et de recherche français ou étrangers, des laboratoires publics ou privés. 


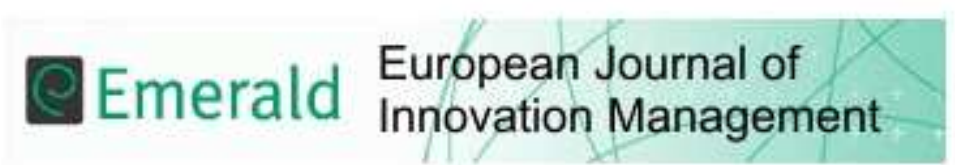

\section{THE LINK BETWEEN NON TECHNOLOGICAL INNOVATIONS AND TECHNOLOGICAL INNOVATION}

\begin{tabular}{|r|l|}
\hline Journal: & European Journal of Innovation Management \\
\hline Manuscript ID: & Draft \\
\hline Manuscript Type: & Original Article \\
\hline Keywords: & $\begin{array}{l}\text { Organizational innovation, Marketing innovation, Technological } \\
\text { Innovation, Performance }\end{array}$ \\
\hline \multicolumn{2}{|l}{} \\
\hline
\end{tabular}

\section{今 ScholarONE \\ Manuscript Central}

Thuc Uyen Nguyen-Thi - CEPS / INSTEAD

Caroline Mothe - IREGE 


\title{
THE LINK BETWEEN NON TECHNOLOGICAL INNOVATIONS AND TECHNOLOGICAL INNOVATION
}

\begin{abstract}
Purpose

This paper aims to provide evidence of the major role of non-technological activities in the innovation process. It highlights the effects of marketing and organizational innovation strategies on technological innovation performance.

\section{Design/methodology/approach}

The article tests theoretical hypotheses on a sample of 555 firms of the $4^{\text {th }}$ Community Innovation Survey (CIS 4) in 2006 in Luxembourg. Data are analyzed through a generalized Tobit model.

\section{Findings}

In the present study, evidence is found to support the impact of innovation in the marketing and organization fields on a firm's capacity to innovate, but not on the innovative performance. The paper also statistically shows that the effects of non-technological innovation differ depending on the phase of the innovation process.
\end{abstract}

\section{Research limitations/implications}

The causal link and the question of time frame between the various innovations could be further investigated, especially through longitudinal studies. Further research should also focus on the differences between large versus small firms, and service versus industrial firms.

\section{Practical implications}

The effects of non-technological innovation are not the same according to whether the firm is in the first step of the innovation process (i.e. being innovative), or in a later step (i.e. innovative performance). Managers should be aware of these various effects in order to efficiently adopt non-technological innovation strategies.

\section{Originality/value}

Few works have taken into account the role of other innovative strategies such as marketing and organization. At our knowledge, this is the first study based on recent CIS data that looks at the interrelations between different types of innovation.

Article type: Research paper

Keywords: Innovation, Marketing, Organization, Performance, Technological

JEL classification: L25, O31, O32 
INTRODUCTION

Innovation has become one of the main priorities of most countries. The European Union, through the Lisbon strategy, aims at stimulating national R\&D investments in order to reach the "ideal" 3\% GDP level. Many studies have used R\&D expenditure as a measure of the capacity of a firm to innovate. While emphasizing innovation input and support instruments, these works did not take into account other types of innovation strategies such as marketing or organization. The literature on innovation nevertheless highlights the iterative nature of the innovation process where non-technological activities play a crucial role. In line with this idea, the Community Innovation Survey's (CIS) fourth study (covering the period from 20022004) has introduced measures on innovation in marketing and organization.

Research in the Resource-Based View, in the footsteps of Penrose (1959) and Wernerfelt (1984), has highlighted the importance of managing and combining different types of resources, and even of reconfiguring various capabilities, thus giving birth to the dynamic capabilities' approach (Teece, Pisano and Shuen, 1997). Firms are to organize the innovation process efficiently by combining technological capabilities with skills in marketing, management as well as organizational competencies.

Empirical research has tested how organizational learning capability affects product innovation performance (Alegre and Chiva, 2008) and, more generally, has investigated the numerous factors that influence innovative performance (Hall and Bagchi-Sen 2007). Schmidt and Rammer (2007) concentrated on the determinants of the various types of innovation and showed that they were very much identical with a significant rho between technological and non technological innovations. Another important result was that the combination of technological and non technological innovation has a positive impact on a firms' return on sales. Surprisingly, this effect could only be related to the combination of organizational and product innovation. No other combinations of technological and non-technological innovation lead to a significantly higher return on sales.

Here we studied the relationship between non technological innovations and technological innovation. It is surprising to note that little has been written on the care firms should take when considering the types of innovation that may lead to technological innovation, such as innovation in organization and/or in marketing. Both types of innovation were, however, included in the third edition of the Oslo Manual (2005), thus expanding the definition of innovation. They are now considered as innovation types that should be differentiated from technological innovation.

The question of how these two other types of innovation may impact technological innovation is an important issue as it changes factors determining technological innovation that may be a key to a firms' performance. The focus is usually on R\&D investment. However, not all firms are R\&D intensive, even in the biotechnology sector (Hall and BagchiSen, 2007). Firms with a relatively lower R\&D intensity attribute their innovation performance to strategies that focus on competitiveness, marketing, or distribution channels (Hall and Bagchi-Sen, 2007), i.e. on marketing innovation. In the same vein, and extending the recent interdisciplinary research showing that customer and technological skills have a direct, unconditional effect on a firms' innovative performance, Lokshin, van Gils and Bauer (2008) consider the effect of organizational skills. If they do not directly improve innovative performance, the firms that successfully combine customer, technological and organizational skills will bring more innovations to the market.

Following this line of research, the purpose of this paper is to highlight, through a multidisciplinary view of innovation (Tatikonda and Montoya-Weiss 2001), the effects of 
non-technological innovation strategies on firms' technological innovation. Our work is in line with Armbruster et al. (2008) who recommend to go further in the comprehension of the distinct types of innovation, and especially of organizational and marketing innovations. It also provides a comparison with the research Schmidt and Rammer (2007) undertook on the CIS4 data in Germany, analysing the spread of non technological innovation in firms and its relationship with technological innovation. However, our approach differs slightly. Whereas these authors focus on the determining factors of non technological innovation and study their effect on return of sales; our objective is to determine the effect of non-technological innovation on product innovation (through the propensity to innovate) and on its success (through the turnover due to new products).

When examining the impact of non-technological innovation on technological innovation, we first provide an overview of organizational and marketing innovations and present different hypotheses (Section 2). Second, we outline the dataset, variables and method, based on the large-scale fourth Community Innovation Survey (CIS4), carried out in Luxembourg over the period from 2002-2004 (Section 3). We then present and discuss the results and show how different precedents lead to different results in the capacity to innovate and in innovative performance (Section 4). Based on these considerations, we conclude on the necessity to better apprehend organizational and marketing innovation, and provide avenues for further research (Section 5).

\section{THEORETICAL BACKGROUND AND HYPOTHESES}

Innovation has been defined as the adoption of an idea, behavior, system, policy, program, device, process, product or service that is new to the organization (Damanpour, 1992). If, for Damanpour, organizational innovation concerns all parts of the organization, thus including all types of innovation, innovation is often divided into technological innovation and organizational innovation. Phillips (1997), for instance, separates technological and nontechnological innovation, and includes new marketing strategies and changes to management techniques or organizational structures in the latter category. Technological innovation is usually seen as encompassing product and process innovation. Here we concentrate on product innovation, defined as the introduction of goods or services that are new or significantly improved with respect to their specifications or intended uses. This includes significant improvements in technical specifications, components and materials, incorporated software, user friendliness or other functional characteristics (OCDE, 2005). We will therefore look at the introduction of products that are new to the firm, which includes small and gradual improvements within firms - and not only more radical types of innovation in terms of products that are new to the market.

Our objective is to evaluate firm performance in terms of product innovation (or innovative performance). Our approach is output based, and can be the introduction of new products, or a percentage of sales generated from new or improved products (Cassiman and Veugelers, 2006).

\subsection{Organizational and product innovations}

Theoretically, organizational innovation (OI) is a broad concept that encompasses strategies, structural and behavioral dimensions (Gera and $\mathrm{Gu}, 2004$ ). The notion of OI is subject to various definitions and interpretations (Lam, 2004). Black and Lynch (2005) view OI as including components such as workforce training, work design (more decentralized and 
flexible allocation of labor in the firm), employee voice (allowing workers to have greater autonomy and discretion in their work) and shared rewards (incentives such as profit sharing or stock options). In the present research, we adopt the definition proposed by the Oslo Manual (OCDE, 2005, 51): "An organizational innovation is the implementation of a new organisational method in the firm's business practices, workplace organisation or external relations". According to OECD (2005), Murphy (2002) and Uhlaner et al. (2007), OI encompasses three types of practice: (a) management practice (teamwork, knowledge management, flexible work arrangements); (b) production approaches (change to the work organization: total quality management, business re-engineering) and (c) external relations (outsourcing, networking, customer relations).

Firms who are active in technological innovation (TI) usually adopt complementary organizational practices. Numerous studies have investigated the complementarity between OI and TI by highlighting the importance of technological innovation as a driver of organizational changes within the firm (Henderson and Clark 1990; Dougherty 1992; Danneels 2002). These studies have focused on the fact that TI usually conduces to OI. Firms introducing TI would therefore be constrained to reorganize their production, workforce, sale and distribution systems. Another research stream points out the inverse relationship by stressing the role of OI in enhancing flexibility, creativity - that in turn facilitates the development of TI. Using a sample of firms in the fast-moving consumer goods industry in Germany, Lokshin, van Gils and Bauer (2008) studied the effect of organizational skills on firms' innovative performance, showing that firms implementing a combination of customer, organizational and technological skills tend to introduce more innovation. Whatever the research perspective, the crucial role of organizational practices on competitive edge and firm performance is acknowledged. Organizational practices are considered as an input to the firm's innovation process and to its innovation capability. Consequently, we consider the following hypothesis:

Hypothesis 1: The higher a firm's organizational innovation, the higher (a) its propensity to innovate and (b) its innovative performance.

The first category of organizational innovation refers to the introduction of knowledge management systems. Knowledge management here includes practices such as management skills or sharing, coding and storing knowledge, and is usually associated with higher flexibility, adaptability, competitive advantage and organizational performance (Prahalad and Hamel, 1990; Grant, 1996; Spicer and Sadler-Smith, 2006). Firms have opportunities for higher innovation capabilities and performance when they are able to expand, disseminate and exploit organizational knowledge internally, as well as to share, transfer and receive knowledge from external partners. Empirical results are more doubtful as to the effect of knowledge management on firm performance. Many studies recognize the positive impact of KM strategies but few provide conclusive evidence (Becerra-Fernandez and Sabherwal, 2001) or even a weak significance of the relationship between the two (Chen, Feng and Liou, 2004). Shin (2004) underlines that the high costs generated by the implementation of such a strategy may impede a firms' performance. The absence of a positive relation may also be explained by the significant delay usually associated with the return on investment of such a long term maturity strategy. Using a sample of manufacturing firms surveyed in the third French CIS, Kremp and Mairesse (2004) found, however, that firms having knowledge management policies are likely to innovate more extensively and to have higher productivity. Uhlaner et al. (2007) showed, for a panel of Dutch firms, that firms implementing knowledge management have higher growth than others. We therefore propose to test the following hypothesis: 
Hypothesis 1.1: The higher a firm's use of knowledge management systems, the higher (a) its propensity to innovate and (b) its innovative performance.

The second category of organizational innovation refers to the change to the work organization. The European Commission's 1997 Green Paper sees it a key priority for higher competitiveness, based on high skills, reliability and quality. According to OECD (2005), new work practices are related to lean and just-in-time production, decentralized decision-making, team work and shared rewards. Implementing new work organization could result in substantial improvements in organizational flexibility which in turn lead to improved firm efficiency and performance. Previous empirical studies show, however, controversial results on the benefits of changes in work organization. Ichniowski, Shaw and Prennushiwski (1997) found, on a sample of 36 homogeneous steel production lines, that using a set of innovative work practices such as teams, flexible job assignments or training leads to higher output levels and product quality. Using US detailed firm-level data, Bresnahan, Brynjolfsson and Hitt (2002) highlighted the complementary nature of product and service innovation, information technology and workplace reorganization. They showed that new work practices only result in improvements in firm performance when they are combined with heavy investments in either human capital or ICT. We therefore propose to test the following hypothesis:

Hypothesis 1.2: The higher a firm's change in work organization, the higher (a) its propensity to innovate and (b) its innovative performance.

The third organizational practice refers to relations with other firms or public institutions, through alliances, partnerships, outsourcing or sub-contracting. The growing role of networking in firms' innovative capabilities is closely linked to the context of the emerging knowledge-based global economy. Because of the tacit and non transferable character of knowledge and of the evolutionary and continual character of the learning process, innovative firms should concentrate on their specific capabilities while involving in cooperative arrangements in order to develop new skills and extensions of the firm's know-how to new applications. Firms should moreover be encouraged to engage in external relations in order to have access to partners' complementary or synergistic skills and capitalize "incoming spillovers" (Kogut, 1988; Kogut and Zander, 1993; Cassiman and Veugelers, 2002), to reduce the duplication of R\&D efforts as well as risks and costs associated to innovation projects (Jacquemin, 1988; Sakakibara, 1997) and to benefit from economies of scale or scope (Kogut, 1988).

Different motives are attributed to cooperation differentiated by types of partner. Vertical cooperation with customers and suppliers is theoretically assumed to enhance firm efficiency by reducing the uncertainty related to the introduction of new products or services on the market, contributing vital information on technologies and changing market needs and facilitating market expansion, particularly when the innovation is new and complex (von Hippel, 1988; Klomp and van Leeuwen, 2001). The interest for horizontal cooperation with competitors can be more complex (Hamel, Doz and Prahalad, 1989; Tether, 2002). While sharing the main features of vertical partnerships, i.e. reducing costs and risks for large projects, cooperation with competitors can be dangerous because of the potential for anticompetitive behaviour and the risks related to involuntary "outgoing spillovers" to partners (Cassiman and Veugelers, 2002; Tether, 2002; Belderbos, Carree and Lokshin, 2004). Firms may also be motivated to cooperate with universities and research institutes for new scientific 
and technological knowledge, i.e. technology evaluation, anticipation of social effects, access to equipment and techniques, new technological options, etc. This type of cooperation often involves large firms which have internal $R \& D$ structures and benefit from public funding (Sakakibara 1997, 2001). We propose to test the following additional hypothesis:

Hypothesis 1.3: The higher a firm's engagement in external relations, the higher (a) its propensity to innovate and (b) its innovative performance

\subsection{Marketing and product innovations}

Rust et al. (2004) view marketing innovation (MI) in terms of three dimensions: (1) product strategy; (2) price strategy and (3) promotion strategy. These strategies lead to tactical marketing actions such as changes in design or packaging, changes in sales or distribution methods, advertising or permanent exhibitions. The objectives are to increase the attractiveness of firms' products or services and/or to enter new markets.

Marketing innovation is, in the $3^{\text {rd }}$ edition of the Oslo Manual, clearly distinguished from product innovation, as the latter includes technical specifications and functional characteristics, while the first is defined as "the implementation of a new marketing method involving significant changes in product design or packaging, product placement, product promotion or pricing" (OECD, 2005, 49).

Theoretically, marketing initiatives are tactical actions and intangible resources that determine firm performance (Wernerfelt, 1984; Barney, 1991; Grant, 1996; Teece, Pisano and Shuen, 1997). Firms focusing attention on marketing initiatives are likely to have a better ability to increase customer satisfaction compared to competitors (Baker and Sinkula 1999), to successfully adapt to changing market needs, to discover and exploit business ideas and to access new information and resources for developing new competitive products or processes (Day, 1994; Rust et al., 2004). Many empirical studies acknowledge this positive impact (Day, 1994; Slater and Narver, 2000). They highlight the importance of a firms' environmental context. The positive impact of marketing on firm performance would be moderated by a weak economy, high market turbulence and competition (Kohli and Jaworski, 1990). Also, market orientation leads to higher business profitability when it relates to learning from external relations such as clients or competitors. Accordingly, we propose to test the following hypothesis:

Hypothesis 2: The higher a firm's marketing innovation, the higher (a) its propensity to innovate and (b) its innovative performance.

Changes to the design and packaging of products as a type of marketing innovation could be an integral part of the innovation process. Besides product protection and transport optimization, packaging and design may influence consumer behaviour and the decision process at the purchase point. In other words, they might be an art of communication aimed at conveying information from producers to consumers on a market characterized by an abundance of products and increased competition. Moreover, in a globalization context, expansion and new market shares largely depend on the efficiency of packaging and design adapted to the specific needs, requirements and culture of the importing country's consumers as well as on the cost savings made by appropriate packaging. Therefore, we will test the following hypothesis: 


\subsection{Dataset}

The firm-level dataset drawn from the Luxemburg Community Innovation Survey (CIS4) for the period from 2002 to 2004 was used here. Despite Luxemburg's economic growth, the innovation system is relatively young and not yet fully developed. In 2000, R\&D intensity (i.e. R\&D expenditures as a percentage of GDP) in Luxembourg represented $1.71 \%$ - of which $90 \%$ was from the private sector. For some years, the government has considered innovation as a national priority. While considerably increasing public support for innovation, Luxembourg has an advantageous geographical location within the European Research Area ("La Grande Région"), which increases the favorable conditions for research and innovation. It also has the advantage of being a nation where services, especially in the finance and intermediation activities, are important, thereby allowing us to compare service and industrial activities on the one hand, and to see whether there are major differences between large and small firms.

We used the fourth Community Innovation Survey (CIS4) of Luxembourg's firms over the period 2002-2004. It was coordinated by EUROSTAT and carried out in 2006 by CEPS/INSTEAD ${ }^{1}$ in collaboration with STATEC ${ }^{2}$. A sample of 555 representative firms with a least 10 employees in the manufacturing $(43 \%)$ and the service $(57 \%)$ sectors is used. Of these 555 firms, $490(88 \%)$ are of small and medium size ( $<250$ employees).

Our main objective is to study the effect of non-technological innovation strategies, here defined as organizational and marketing innovation, on technological innovation. Two dependent variables are used. Similarly to Veugelers and Cassiman (2004), we determine the first one as the propensity to innovate (PROD_INN). It is based on the "yes-no" question on the introduction by firms of new or significantly improved products during the three years from 2002 to 2004. Of 555 firms, 225 (41\%) declared themselves to be innovative. The

\footnotetext{
${ }^{1}$ International Network for Studies in Technology, Environment, Alternatives, Development

${ }^{2}$ Central Service of Statistics and Economic Studies
} 
second, namely innovative performance (PERFOR), is measured as the percentage of total turnover from product innovation that is new to the firm (Cassiman and Veugelers, 2006).

Of particular interest to this study are the survey questions in which firms are asked whether they introduce non-technological innovation (organization and marketing). All firms, whether innovative (in terms of technological innovation) or not, had to answer to these questions.

The first type of non-technological innovation is organizational innovation. Three organizational innovation practices are categorized: the introduction of new or significantly improved knowledge management systems (ORG_SYS), the introduction of major changes to the work organization within the firm (ORG_STR) and the introduction of new and significant changes in relationships with other firms or public institutions (ORG_REL). A composite measure of organizational innovation (ORG_INN) is also introduced, taking the value 1 if firms performed at least one of the above practices. $60 \%, 56 \%$ and $35 \%$ of innovative firms implement knowledge management, work organization and external relations respectively.

The second type of non-technological innovation is marketing innovation - which is clearly distinguished from technological innovation in the CIS survey. It provides information on two practices: the introduction of significant changes to the design or packaging of goods or services (MKT_DES) and the introduction of changes in sales or distribution methods (MKT_MET). The composite measure of marketing innovation (MKT_INN) is equal to 1 if firms introduced at least one of these two practices. Of the innovative firms, $31 \%$ introduced changes in design and packaging and $33 \%$ changes in sales and distribution methods. Definitions and descriptive statistics are given in Appendices A and B.

\subsection{Empirical method}

To assess the impact of organizational and marketing innovation on innovative performance, we estimate the following function:

$$
Y_{i}=N T_{i}^{\prime} \alpha+X_{i}^{x} \beta+\varepsilon_{i}
$$

where $Y_{i}$ is innovative performance for firm $i$, measured as the share in sales of innovative products (PERFOR). $N T_{i}$ represents the set of organizational and marketing innovation variables. $X_{i}$ is the vector of independent variables, including controls for firm-level heterogeneity such as firm size, sectors of activity, foreign ownership and also a set of variables which have previously been shown to be relevant determinants of innovative performance at the firm level, such as the intensity of internal and external R\&D, external sources of information, cooperation with different types of partners, obstacles to innovation or the use of intellectual property rights. Descriptive statistics and variable definitions are provided in Appendices A, B and C. $\beta$ and $\alpha$ are the vectors of associated coefficients.

Since the dependent variable measures the percentage of total turnover from innovative products, we only draw on the sub-sample of innovative firms from the dataset. Therefore, left-censoring arises when many firms in our sample do not innovate at all.

If censoring is not accounted for, the estimation of innovative performance could be biased and misleading. In order to correct for censoring and to assess the impact of organization and marketing innovations on the probability of firms to become innovative, and as the probability to innovate and the financial success of innovative products represent 
two separate phases of the innovation process, we specify a probit model for the probability to innovate. The function can be written as follows:

$$
Z_{i}=N T_{i}^{\prime} \gamma+W_{i}^{x} \delta+u_{i}
$$

where $Z i$ is the latent variable corresponding to the probability to innovate (PROD_INN). Innovating firms have positive values for $Z i$ and non-innovating firms have negative values. $N T_{i}$ is the set of organization and marketing variables. $W_{i}$ is the set of control variables, including firm size, sectors of activity, foreign ownership and obstacles to innovation. Other variables such as R\&D cooperation, sources of information, etc; which are introduced in the first step for estimating the innovative performance (Equation 1) are not included here (Equation 2) because this data is only available for innovative firms. $\gamma$ and $\delta$ are the vectors of associated coefficients.

As dependent variables in equation 1 and 2 are respectively the percentage of sales due to innovative products and the probability to innovate, consistent estimates for the parameters of interest can be obtained by maximum likelihood estimation of a generalized Tobit that accounts for censoring in innovative performance (Mohnen and Röller, 2005). The inverse Mill's ratio included in the model for correcting left-censoring is not significant. This indicates that the estimation results for PERFOR are not influenced by censoring.

\section{RESULTS AND DISCUSSION}

Table I presents estimation results of the generalized Tobit model. Models 1 and 2 include composite measures of organizational and marketing innovations for the probability to innovate and the innovative performance. Models 3 and 4 include different practices of these two types of innovation.

The aggregated measure of organizational innovation has a strong positive impact on firms' probability to innovate, in line with Hypothesis la (Model I). However, we detect no impact of OI on innovative performance, thus invalidating Hypothesis $1 b$ (Model 2). In line with the literature (Dougherty 1992; Danneels 2002), we expected a positive effect of this type of innovation: firms devoting efforts to managerial practices or new organizational forms should be more able to efficiently use new skills and technologies.

When differentiated by types of practice, the introduction of new or significantly improved knowledge management systems is found to have a significant effect on the propensity to innovate (Model 3). Firms implementing knowledge management are thus more likely to have a higher ability to innovate. This tends to corroborate the idea that knowledge management strategies are associated with more flexibility, adaptability, competitive advantage and better organizational performance. Firms have opportunities to increase their innovation capabilities when they are able to expand, disseminate and exploit organizational knowledge internally, as well as to share, transfer and receive knowledge from external partners. This is, moreover, reinforced by the positive effect of sources of information from R\&D institutes on firms' innovative capacity in our model.

However, there is no effect of both organizational practices on innovative performance (Model 4). The absence of such a relation may be due to the substantial time lag usually associated with the return on investment of such a long-term strategy. When implementing 
organizational changes such as new work organizations or new knowledge management systems, employers and employees are involved in a long term process of adaptation and learning which does not immediately result in substantial improvement in innovative performance.

Results also show that cooperation with customers has a positive impact on performance. This is in line with the idea that cooperating with customers allows for a better understanding of new market needs and demands, enabling to define the rate and direction of innovation as well as to anticipate market trends (Klomp and van Leeuwen, 2001). Surprisingly, cooperation with suppliers has a negative effect: the more collaboration with suppliers, the lower the innovative performance. This result is unexpected but could be explained by the fact that firms use cooperation with suppliers mainly for cost reduction. They are thus likely to focus less attention on other important aspects of innovation processes, such as product innovation. It could also be caused by the fact that suppliers are often large firms which have a high negotiating power against small firms (which constitute almost $90 \%$ of the sample) and tend to collaborate for other reasons than to increase innovative capacities of subcontractors.

Cooperation with competitors or other firms in the same sector has no impact on performance. $R \& D$ cooperation with universities and public research institutes has a slightly negative effect on innovative performance. This is in contrast with the findings of Belderbos, Carree and Lokshin (2004) for Dutch firms, or Lööf and Heshmati (2002) for Swedish firms. For our sample, the result might be explained by the long-term nature of this type of cooperation where research tends to be of a more generic and basic nature. Therefore, one cannot not observe the results of such an alliance immediately, and there may even be a negative effect in the short term. 
Table I Estimation results of the generalized Tobit model

\begin{tabular}{|c|c|c|c|c|}
\hline & Probability to innovate & Innovative Performance & Probability to innovate & Innovative Performance \\
\hline & Model 1 & Model 2 & Model 3 & Model 4 \\
\hline ORG_INN & $0.41^{* * * * *}(0.004)$ & $-0.05(0.292)$ & & \\
\hline ORG_SYS & & & $0.284^{*}(0.056)$ & $-0.032(0.331)$ \\
\hline ORG_STR & & & $0.109(0.381)$ & $-0.007(0.818)$ \\
\hline ORG_REL & & & $0.018(0.909)$ & $0.010(0.692)$ \\
\hline MKT_INN & $0.83^{* * * *}(0.000)$ & $-0.00(0.951)$ & & \\
\hline MKT_DES & - & & $0.602^{* * * *}(0.001)$ & $-0.027(0.590)$ \\
\hline MKT_MET & - & & $0.545^{* * *}(0.002)$ & $-0.009(0.858)$ \\
\hline INTEN_RD & - & $0.18^{*}(0.058)$ & - & $0.151^{*}(0.100)$ \\
\hline CO_CLI & - & $0.08^{* *}(0.037)$ & - & $0.085^{* * * *}(0.004)$ \\
\hline CO_SUP & - & $-0.07^{* * *}(0.012)$ & - & $-0.064^{* * *}(0.047)$ \\
\hline CO_INSTI & - & $-0.04(0.164)$ & - & $-0.058^{*}(0.079)$ \\
\hline CO_CONC & - & $0.02(0.580)$ & - & $0.013(0.687)$ \\
\hline SO_RD & - & $0.09(0.168)$ & - & $0.091(0.185)$ \\
\hline SO_PUB & - & $-0.08(0.167)$ & - & $-0.075^{*}(0.086)$ \\
\hline SO_MAR & - & $-0.02(0.477)$ & - & $-0.021(0.469)$ \\
\hline DEM_PULL & - & $0.036(0.599)$ & - & $0.037(0.613)$ \\
\hline COS_PUSH & - & $0.179^{* * * *}(0.000)$ & - & $0.162^{* * *}(0.001)$ \\
\hline PR_AVAN & - & $-0.079^{* * * * *}(0.003)$ & - & $-0.079^{* *}(0.011)$ \\
\hline PR_PAT & - & $-0.028(0.415)$ & - & $-0.024(0.638)$ \\
\hline PR_TM & - & $-0.026(0.365)$ & - & $-0.026(0.478)$ \\
\hline PR_SECR & - & $0.030(0.295)$ & - & $0.023(0.467)$ \\
\hline H_COS & $0.33^{*}(0.086)$ & $-0.006(0.873)$ & $0.344^{*}(0.071)$ & $-0.013(0.739)$ \\
\hline H_KNO & $0.04(0.829)$ & $-0.006(0.873)$ & $0.044(0.830)$ & $-0.045(0.302)$ \\
\hline H_MAR & $-0.13(0.561)$ & $0.010(0.774)$ & $-0.101(0.490)$ & $0.016(0.699)$ \\
\hline SIZE & $0.17^{* * * *}(0.003)$ & $-0.035^{* * * *}(0.012)$ & $0.174^{* * *}(0.001)$ & $-0.040^{*}(0.060)$ \\
\hline M_HMH & $0.64^{* *}(0.023)$ & $-0.112(0.155)$ & $0.625^{* * *}(0.024)$ & $-0.124(0.126)$ \\
\hline M_MED & $-0.02(0.928)$ & $-0.053(0.457)$ & $0.009(0.969)$ & $-0.050(0.585)$ \\
\hline M_LOW & $-0.17(0.441)$ & $0.012(0.821)$ & $-0.191(0.444)$ & $0.025(0.731)$ \\
\hline S_TRANS & $-0.31(0.172)$ & $-0.052(0.373)$ & $-0.349(0.165)$ & $-0.039(0.652)$ \\
\hline S_FINAN & $0.64^{* * * *}(0.008)$ & $-0.104(0.130)$ & $0.594^{* *}(0.012)$ & $-0.114(0.124)$ \\
\hline S_COMP & $1.09^{* * * *}(0.000)$ & $-0.145(0.123)$ & $1.073^{* * *}(0.000)$ & $-0.181^{*}(0.081)$ \\
\hline S_RD & $0.82^{* * *}(0.003)$ & $-0.072(0.446)$ & $0.765^{* * *}(0.016)$ & $-0.081(0.429)$ \\
\hline NA_GP & $0.22(0.248)$ & $-0.021(0.606)$ & $0.216(0.226)$ & $-0.030(0.546)$ \\
\hline EU_GP & $0.39^{* *}(0.015)$ & $-0.014(0.805)$ & $0.418^{* * * *}(0.006)$ & $-0.029(0.555)$ \\
\hline EXTRA_GP & $0.46^{* *}(0.025)$ & $-0.013(0.826)$ & $0.433^{* *}(0.041)$ & $-0.024(0.680)$ \\
\hline Constant & $-1.95^{* * * *}(0.000)$ & $0.483^{*}(0.097)$ & $-1.848^{* * *}(0.000)$ & $0.548^{*}(0.058)$ \\
\hline \# obs. & 555 & 225 & 555 & 225 \\
\hline Rho & $-0.058(0.045)$ & & $-.0 .030(0.032)$ & \\
\hline Wald $\chi^{2}$ & $191.5^{* * * *}$ & & $159.8^{* * * *}$ & \\
\hline$p$-value & 0.000 & & 0.000 & \\
\hline
\end{tabular}

Note: $*, * *$ and $* * *$ denote significance at the level of $10 \%, 5 \%$ and $1 \%$ respectively. Robust $p$ values are in parentheses. 
As for marketing innovation, the results indicate that there is no impact of the aggregated measure and of the separate practices on innovative performance (Models 2 and 4). This can be understood as the two types of marketing innovation are quite different: incremental changes on design and packaging of products on the one hand (MKT_DES) and changes in the sales organization on the other (MKT_MET). Thus, a firm (especially a small and/or a service activities firm) may use one type of marketing innovation, but not the other. We find that MI and the two types of practice are significant for the propensity to innovate. This finding, validating Hypothesis $2 a, 2.1 a$ and $2.2 a$ highlights the fact that firms consolidate through marketing practices, relations with business partners and customers, learn about changing market needs and capture market information - which in turn enhance their capacity to innovate.

We also found that innovative performance is higher for firms that invest intensively in either internal or external R\&D. This is in line with previous empirical findings indicating the crucial role of $R \& D$ expenditures in the innovation process as it conditions knowledge creation as well as firms' capacity to absorb external knowledge (Grilliches and Mairesse, 1984; Crépon, Duguet and Mairesse, 1998). While confirming the acknowledged role of R\&D expenditures (intracompany and/or extra company) in enhancing innovative performance, we observe that the impact of $R \& D$ intensity is low. This could be explained by the fact that $R \& D$ investment is usually made by big firms. In our sample, almost $90 \%$ of the firms are small and medium sized. Thus, in the case of Luxembourg, it might be important to consider not only R\&D investment to explain firm performance, but also other strategies.

Among the set of control variables, firm size affects the propensity to innovate positively but innovative performance negatively, corroborating previous empirical literature. This could be due to mechanical effects as small innovating firms have a smaller product portfolio: thus, when small firms engage in product innovation activities, the part of innovation will be higher in the overall turnover than for large firms, for which innovative activities are much more diluted. Surprisingly, we find no effect of demand-related objectives on firm performance. In contrast, a positive effect of cost-related objectives on innovative performance is detected. This indicates that cost reduction is considered as an important strategy due to economies of scale and learning-by-doing effects. When taking the wholesale trade as reference, we find that belonging to more technologically advanced manufacturing industries and/or to knowledgeintensive services (such as financial intermediation, $\mathrm{R} \& \mathrm{D}$, engineering activities or consultancy) increases the probability of introducing new products and services.

Another interesting result is that firms using lead-time advantage on competitors as an informal method of innovation protection have a lower innovative performance (other methods of protection, such as patents and trademarks, have no significant impact). This is in line with the idea that being first-mover does not always provide a significant advantage in terms of innovation, and that second-movers benefit from an experience that is more useful in terms of performance than being the first on the market (Bocquet, Brossard and Sabatier, 2007).

\section{CONCLUSION AND SUGGESTIONS FOR FUTURE RESEARCH}

The recent literature on innovation highlights the iterative character of innovation processes where non-technological activities play a crucial role. We tested the impact of both organizational and marketing innovation in order to capture such effects. Our study strongly highlights the importance of marketing innovation as a non-technological innovation activity for the propensity to innovate. Similarly, results for organizational innovation show that firms enhance their capacity to innovate, but not their innovative performance when adopting 
organizational strategies. Both organizational and marketing innovations lead to a higher propensity to introduce new or improved products or services. However, when considering the innovative performance in terms of percentage of sales of new products, marketing and organizational innovations do not lead to higher innovative performance. These results point out the fact that the effects of non-technological innovation are not the same according to whether the firm is in the first step of the innovation process (i.e. being innovative), or in a later step (i.e. performing as far as innovation is concerned). Managers should therefore be aware of the various effects in order to efficiently adopt non-technological innovation so that firms can benefit from its full potential.

More research should therefore be undertaken to study the links between product innovation and non technological innovations. The comparison between research using different measures could be stimulating to assess the various types of innovation. Indeed, as discussed by Armbruster et al. (2008), it would be interesting to compare results with other large-scale surveys (NUTEK, DRUID, EPOC, INNFORM, COI) that use other measures both for organizational and marketing innovation, and for the performance of technological innovation. In addition, future research could analyze the impact of non technological innovations on process innovation, in line with Schmidt and Rammer (2007).

The results therefore offer some clues for policy-makers in order to favor nontechnological innovations within the firm. Further research should be undertaken to better understand the impact of non-technological innovations on performance by taking into account the difference between large firms vs. small and medium firms, industrial vs. service firms, and also to allow for an appropriate time lag in order to assess the long-term impact of organizational or marketing innovation on performance. Future research should also investigate the impact of firm size on non-technological activity strategies to enhance performance as far as technological innovation is concerned. Differences between large versus small firms, and service versus industrial firms, could not be tested in this study due to the too small size of the sample, and should be further investigated. The present study does not provide information about the causality between technological and non-technological innovations which can be an interesting research perspective. Finally, the time frame between the introduction of a non-technological innovation and its impact on technological innovation success needs to be analyzed through longitudinal studies.

\section{References}

Alegre, J. and Chiva, N.T. (2008), "Assessing the impact of organizational learning capability on product innovation performance: An empirical test", Technovation, Vol. 28, pp. 315-326.

Armbruster, H., Bikfalvib, A., Kinkela, S. and Lay, G. (2008), "Organizational innovation: The challenge of measuring non-technical innovation in large-scale surveys", Technovation, Vol. 28, pp. 644-657.

Baker, W.E. and Sinkula, J.M.. (1999), "The synergistic effect of market orientation and learning orientation on organizational performance", Journal of Academy of Marketing Science, Vol. 27 No. 4, pp. 411-427.

Barney, J.B. (1991), "Firm Resources and Sustained Competitive Advantage", Journal of Management, Vol. 17, pp. 99-120.

Becerra-Fernandez, I. and Sabherwal, R. (2001), "Organizational Knowledge Management: A Contingency Perspective", Journal of Management Information Systems, Vol. 18 No. 1, pp. 23-55.

Belderbos, R., Carree, M. and Lokshin, B. (2004), "Cooperative R\&D and Firm Performance", Research Policy, Vol. 33, pp. 1477-1492.

Black, S.E. and Lynch, L.M. (2005), "Measuring Organizational Capital in the New Economy", in Carol, C., Haltiwanger, J., and Sichel, D. (Eds), Measuring Capital in the New Economy, University of Chicago Press. 
Bocquet, R., Brossard, O. and Sabatier, M. (2007), "Complementarities in organizational design and the diffusion of information technologies: An empirical analysis", Research Policy Vol. 36 No. 3, pp. 367-386.

Bresnahan, T.F., Brynjolfsson, E. and Hitt, L.M. (2002), "Information Technology, Workplace Organization, and the Demand for Skilled Labor: Firm-Level Evidence", The Quarterly Journal of Economics, Vol. 117 No. 1, pp. 339-376.

Cassiman, B. and Veugelers, R. (2002), "R\&D Co-operation and Spillovers: some empirical evidence from Belgium”, American Economic Review, Vol. 92 No. 4, pp. 1169-1184.

Cassiman, B. and Veugelers, R. (2006), "In Search of Complementarity in Innovation Strategy: Internal R\&D, Cooperation in R\&D and external Technology Acquisition", Management Science, Vol. 52 No. 1, pp. 68-82.

Chen, E.T., Feng, K. and Liou, W. (2004), "Knowledge Management Capability and Firm Performance: An Empirical Investigation", paper presented at the 10th Americas Conference on Information Systems, August 5-8, in New York.

Crépon, B., Duguet, M. and Mairesse, J. (1998), "Research and Development, Innovation and Productivity: An Econometric Analysis at the Firm Level", Economics of Innovation and New Technology, Vol. 7 No. 2, pp. 115-158.

Damanpour, F. (1992), “Organizational Size and Innovation”, Organization Studies, Vol. 13 No. 3, pp. 375-402.

Danneels, E. (2002), "The Dynamics of Product Innovation and Firm Competencies", Strategic Management Journal, Vol. 23, pp. 1095-1121.

Day, G.S. (1994), "The capabilities of market-driven organizations", Journal of Marketing, Vol. 58, pp. 37-52.

Dougherty, D. (1992), "A Practice-Centered Model of Organizational Renewal through Product Innovation", Strategic Management Journal, Vol. 23, pp. 77-92.

European Commission. (1997), "Green Paper", available at: http://europa.eu.int/comm/employment_social (accessed 12 November 2009)

Gera, S. and W. Gu. (2004), "The Effects of Organizational Innovation and Information and Communications Technology on Firm Performance", International Productivity Monitor, Vol. 9, pp. 37-51.

Grant, R.M. (1996), «Toward a Knowledge-base Theory of the Firm", Strategic Management Journal, Vol. 17, pp. 109-122.

Grilliches, Z. and Mairesse, J. (1984), "Productivity and R\&D at the Firm Level", in Grilliches, Z. (Ed.), R\&D, Patents and Productivity. Chicago Press.

Hall, L.A. and Bagchi-Sen, S. (2007), "An analysis of firm-level innovation strategies in the US biotechnology industry", Technovation, Vol. 27, pp. 4-14.

Hamel, G., Doz, Y. and Prahalad, C.K. (1989), "Collaborate with your Competitors and Win", Harvard Business Review, Vol. 67 No. 1, pp. 133-139.

Henderson, R. and Clark, K. (1990), "Architectural Innovation: The Reconfiguration of Existing Product Technologies and the Failure of Established Firms", Administrative Science Quarterly, Vol. 35, pp. 9-30.

Ichniowski, C., Sha, K. and Prennushi, G. (1997), "The Effects of Human Resource Management Practices on Productivity: A Study of Steel Finishing Lines", American Economic Review, Vol. 87, No. 3, pp. 291-313.

Klomp, L. and van Leeuwen, G. (2001), "Linking Innovation and Firm Performance: a New Approach", International Journal of the Economics of Business, Vol. 8 No. 3, pp. 343-364.

Kogut, B. (1988), Joint Ventures: Theoretical and Empirical Perspectives, Strategic Management Journal, Vol. 9, pp. 319-332.

Kogut, B. and Zander, U. (1993), "Knowledge of the Firm and the Evolutionary Theory of the Multinational Corporation", Journal of International Business Studies, Vol. 24 No. 4, pp. 625-645.

Kohli, A. and Jaworki, B.J. (1990), "Market Orientation: the Construct, Research Propositions and Managerial Implications", Journal of Marketing Research, Vol. 54, pp. 1-19. 
Kremp, E. and Mairesse, J. (2004), "Knowledge Management, Innovation and Productivity: a firm level exploration based on French Manufacturing data", Working Paper 10237, National Bureau of Economic, available at: http://www.nber.org/papers/w10237.pdf (accessed 12 November 2009).

Jacquemin, A. (1988), "Cooperative Agreements in R\&D and Europe Antitrust Policy", European Economic Review, Vol. 32, pp. 551-560.

Lam, A. (2004), "Organizational Innovation", Working Paper, Brunel Research in Enterprise, Innovation, Sustainability \& Ethics, available at: http://mpra.ub.uni-muenchen.de/11539/ (accessed 12 November 2009).

Lau, K., Lee, K., Lam, P. and Ho, Y. (2001), "Web Site Marketing for the Travel and Tourism Industry", Cornell Hotel and Restaurant Administration Quarterly, Vol. 42, pp. 55-62.

Lokshin, B., van Gils, A. and Bauer, E. (2008), "Crafting Firm Competencies to Improve Innovative Performance", Working Paper, UNU-MERIT, available at: http://www.merit.unu.edu/publications/wppdf/2008/wp2008-009.pdf (accessed 12 November 2009).

Lööf, H. and Heshmati, A. (2002), "Knowledge Capital and Performance Heterogeneity: a Firm-Level Innovation Study". International Journal of Production Economics, Vol. 76 No. 1, 61-85.

Mohnen, P. and Roller, L-H. (2005), "Complementarities in innovation policy", European Economic Review, Vol. 49 No. 6, pp. 1431-1450.

Murphy, M. (2002), "Organizational Change and Firm Performance", Working Paper 14, OECD Science, Technology and Industry, OECD Publishing, available at: http://puck.sourceoecd.org/vl=15772435/cl=24/nw=1/rpsv/cgi-bin/wppdf?file=5lgsjhvj7m41.pdf (accessed November 12 2009).

OECD (2005), Oslo Manual, $3^{\text {rd }}$ edition.

Penrose, E. T. (1959), The Theory of the Growth of the Firm, New York, John Wiley.

Phillips, R. 1997. Innovation and Firm Performance in Australian Manufacturing, Industry Commission, Staff Research Paper, Canberra.

Prahalad, C.K. and Hamel, G. (1990), The Core Competence of the Corporation, Harvard Business Review, Vol. 68 No. 3, pp. 79-91.

Rust, R.T., Ambler, T., Carpenter, G.S., V. Kumar and Srivastava, R.K. (2004), "Measuring Marketing Productivity: Current Knowledge and Future Directions", Journal of Marketing, Vol. 68, pp. 76-89.

Sakakibara, M. (1997), "Heterogeneity of firm capabilities and co-operative research and development: an empirical examination of motives", Strategic Management Journal, Vol. 18 No. 6, pp. 143-16.

Sakakibara, M. (2001), "Cooperative Research and Development: who participates and in which industries do projects take place ?" Research Policy, Vol. 30, pp. 993-1018.

Schmidt, T. and Rammer, C. (2007), Non-technological and Technological Innovation: Strange Bedfellows? Working Paper 07-052, ZEW, available at: ftp://ftp.zew.de/pub/zewdocs/dp/dp07052.pdf (accessed 12 November 2009).

Shin, M. (2004), "A framework for evaluating economics of knowledge management systems", Information \& Management, Vol. 42 No. 1, pp. 179-196.

Slater, S.F. and J.C. Narver. 2000. Market Oriented is more than being Customer-led. Strategic Management Journal 20: 1165-1168.

Spicer, D.P. and Sadler-Smith, E. (2006), "Organizational Learning in Smaller Manufacturing Firms", International Small Business Journal, Vol. 24, No. 2, pp. 133-158.

Tatikonda, M.V. and Montoya-Weiss, M.M. (2001), "Integrating Operations and Marketing Perspectives of Product Innovation: The Influence of Organizational Process Factors and Capabilities on Development Performance", Management Science, Vol. 47 No. 1, pp. 151-172.

Teece, D.J., Pisano, G. and Shuen, A. (1997), "Dynamics Capabilities and Strategic Management", Strategic Management Journal, Vol. 18 No. 7, pp. 509-533.

Tether, B.S. (2002), "Who co-operates for innovation and why? An empirical analysis", Research Policy, Vol. 31, pp. 947-967.

Uhlaner, L., van Stel, A. , Meijaard, J. and Folkeringa, M. (2007), "The Relationship between Knowledge Management, Innovation and Firm Performance: Evidence from Dutch SMEs", 
Working Paper, Scientific Analysis of Entrepreneurship and SMEs, available at: www.eim.nl/smes-and-entrepreuneurship (accessed 12 November 2009).

Veugelers, R. and Cassiman, B. (2004), "Foreign Subsidiaries as a Channel of International Technology Diffusion: some direct Firm Level Evidence from Belgium", European Economic Review, Vol. 48, pp. 455-476.

Von Hippel, E. (1988), The Sources of Innovation, Oxford, Oxford University Press.

Wernerfelt, B. (1984), "A Resource-based View of the Firm", Strategic Management Journal, Vol. 5 No. 2, pp. 171-180.

Wyner, G. (2000), "Learn and Earn Through Testing on the Internet", Marketing Research Vol. 12 No. 3, pp. 37-38. 
Other variables DEM_PULL

Models

Scores of importance of three demand-related objectives of innovation, number between 0 (unimportant) and 3 (crucial): (1) increased range of goods or services; (2) entered new markets or increased market share; (3) improved quality of goods or services (rescaled between 0 and 1 ) 
COS_PUSH Sum of scores of importance of four cost-related objectives of innovation, number between 0 (unimportant) and 3 (crucial): (1) improved flexibility of production or service provision; (2) increased capacity of production or service provision; (3) reduced labor costs per units output; (4) reduced materials and energy per unit output (rescaled between 0 and 1)

PR_AVAN Equal to 1 if the score of importance of protection method "lead-time advantage on competitors" is "crucial", 0 otherwise (scores between 0 , unimportant and 3 , crucial)

PR_PAT Equal to 1 if the score of importance of protection method "patent" is "crucial", 0 otherwise

PR_TM Equal to 1 if the score of importance of protection method "trademarks" is "crucial", 0 otherwise

PR_SECR Equal to 1 if the score of importance of protection method "secrecy" is "crucial", 0 otherwise

H_COS Equal to 1 if the score of importance of at least one of three following obstacles (scores between 0 (unimportant) and 3 (crucial)) is "crucial": (1) lack of funds within your enterprise; (2) lack of finance from sources outside your enterprise;

(3) innovation costs too high, 0 otherwise

H_KNO Equal to 1 if the score of importance of at least one of four following obstacles (scores between 0 (unimportant) and 3 (crucial)) is "crucial": (1) lack of qualified personnel; (2) lack of information on technology; (3) lack of information on market, (4) difficulty in finding cooperation partners for innovation, 0 otherwise

H_MAR Equal to 1 if the score of importance of at least one of two following obstacles (scores between 0 (unimportant) and 3 (crucial)) is "crucial": (1) market dominated by established enterprises; (2) uncertain demand for innovative goods or services, 0 otherwise

SIZE Logarithm of the number of employees

GP

Equal to 1 if no part of group (NO_GP) (reference); equal to 2 if part of a national enterprise group (NA_GP); equal to 3 if part of an European enterprise group (EU_GP); equal to 4 if part of extra-European enterprise group (EXTRA_GP)

Sectors High and medium high-tech manufacturing Industry (M_HMH); Medium low tech manufacturing industry (M_MED); Low tech manufacturing industry (M_LOW); Transport and communication (S_TRANS); Financial intermediation (S_FINAN); Computer activities (S_COMP); R\&D - Engineering activities and consultancy, Technical testing and analysis (S_RD) and Wholesale trade (S_TRA) (reference) 
APPENDIX B Descriptive statistics for main variables used in the model (in \%)

\begin{tabular}{llll}
\hline \hline & $\#$ obs. & $\begin{array}{l}\text { Innovative } \\
\text { firms }\end{array}$ & $\begin{array}{l}\text { Non-innovative } \\
\text { firms }\end{array}$ \\
\hline Total sample & 555 & 41 & 59 \\
ORG_INN & 336 & 77 & 49 \\
ORG_SYS & 258 & 60 & 37 \\
ORG_STR & 243 & 56 & 35 \\
ORG_REL & 141 & 35 & 19 \\
MKT_INN & 167 & 63 & 37 \\
MKT_DES & 101 & 31 & 9 \\
MKT_MET & 118 & 33 & 13 \\
SIZE (10-250) & 490 & 37 & 63 \\
SIZE (>250) & 65 & 68 & 32 \\
NO_GP & 238 & 28 & 72 \\
EU_GP & 151 & 53 & 47 \\
EXTRA_GP & 55 & 56 & 43 \\
Service sectors & 370 & 42 & 58 \\
Manufacturing industry & 185 & 37 & 63
\end{tabular}

Note: $77 \%$ of innovative firms declare to have introduced organizational innovations compared to $49 \%$ for non-innovative firms. 
APPENDIX C Means, Standard Deviations, and Correlations

\begin{tabular}{|c|c|c|c|c|c|c|c|c|c|c|c|c|c|c|c|c|c|}
\hline & Mean & St.dev & (1) & (2) & (3) & (4) & (5) & (6) & (7) & (8) & (9) & (10) & (11) & (12) & (13) & (14) & $(15)$ \\
\hline PERFOR (1) & .113 & .166 & 1.00 & & & & & & & & & & & & & & \\
\hline ORG_INN (2) & .745 & .436 & .177 & 1.00 & & & & & & & & & & & & & \\
\hline ORG_SYS (3) & .572 & .492 & .190 & .752 & 1.00 & & & & & & & & & & & & \\
\hline ORG_STR (4) & .555 & .497 & .168 & .712 & .523 & 1.00 & & & & & & & & & & & \\
\hline ORG_REL (5) & .338 & .474 & .130 & .470 & .285 & .347 & 1.00 & & & & & & & & & & \\
\hline MKT_INN (6) & .433 & .496 & .266 & .319 & .317 & .259 & .221 & 1.00 & & & & & & & & & \\
\hline MKT_DES (7) & .274 & .447 & .239 & .217 & .243 & .242 & .153 & .718 & 1.00 & & & & & & & & \\
\hline MKT_MET (8) & .301 & .459 & .201 & .274 & .283 & .206 & .232 & .791 & .348 & 1.00 & & & & & & & \\
\hline INTEN_RD (9) & .025 & .094 & .184 & .095 & .087 & .072 & .086 & .032 & .069 & .043 & 1.00 & & & & & & \\
\hline DEM_PULL (10) & .699 & .271 & .404 & .272 & .225 & .233 & .204 & .329 & .255 & .271 & .183 & 1.00 & & & & & \\
\hline COS_PUSH (11) & .459 & .295 & .293 & .279 & .200 & .194 & .226 & .221 & .195 & .196 & .102 & .573 & 1.00 & & & & \\
\hline CO_CLI (12) & .247 & .432 & .197 & .1667 & .079 & .102 & .240 & .175 & .185 & .131 & .185 & .368 & .210 & 1.00 & & & \\
\hline CO_SUP (13) & .281 & .450 & .166 & .108 & .099 & .129 & .184 & .144 & .112 & .115 & .081 & .242 & .103 & -.611 & 1.00 & & \\
\hline CO_INSTI (14) & .220 & .415 & .135 & .154 & .064 & .078 & .226 & .192 & .194 & .126 & .200 & .356 & .195 & .723 & .571 & 1.00 & \\
\hline CO_CONC (15) & .149 & .356 & .140 & .211 & .113 & .157 & .223 & .197 & .165 & .195 & .195 & .310 & .208 & .686 & .445 & .670 & 1.00 \\
\hline
\end{tabular}

